Alexander N. Lavrentiev

Professor

Doctor of Arts

Vice-rector for scientific and international work of

the Stroganov Moscow State Academy of Industrial and Applied Arts

e-mail: strog-nauka2011@yandex.ru

Moscow, Russia

ORCID 0000-0001-6986-1229

Researcher ID W-1687-2017

DOI: 10.36340/2071-6818-2021-17-1-95-117

\title{
VYACHESLAV KOLEICHUK AS THE ENGINE OF THE RUSSIAN KINETIC ART. IMAGINARY DIALOGUE AT THE EXHIBITION
}

Summary: The State Tretyakov Gallery hosts a significant exhibition "Laboratory of the Future. Kinetic Art in Russia". Its significance, the influence of the artistic phenomenon of kinetic art itself on domestic art of the $20^{\text {th }}$ and $21^{\text {st }}$ centuries has not yet been fully determined. The exhibition emphasizes kinetic art as one of the central national trends in experimental artistic creativity of the $20^{\text {th }}$ century, even as some kind of a tradition.

On the one hand, the exhibition would have been impossible without the participation of the creators of the Russian avant-garde, the founders of abstract art, the creators of the first abstract sculptures and dynamic structures: V. V. Kandinsky, K. S. Malevich, El Lissitzky, V. E. Tatlin, A. M. .Rodchenko.

On the other hand, recognized masters, inventors of kinetic art in the USSR in the 1960s and 1970s, creators of the synthetic works of art combining the sound, color, form, images and motion are also important: Lev Nusberg's "Group Movement" in Moscow and "KB Prometheus" under the leadership of Bulat Galeev in Kazan, the first kinetic construction at the USSR Exhibition of Economic Achievements Francisco Infante and the dynamic installation "Atom" by Vyacheslav Koleichuk, experiments with electronic sound and acoustics of the Experimental Studio of Electronic Music of Evgeny Murzin, the Theremen Center, created by Andrei Smirnov, space projects

The fact that Vyacheslav Koleichuk's spatial and dynamic objects appeared almost in every section of the exhibition "Laboratory of the Future. Kinetic Art in Russia" is not by chance.

The fact that a double photo portrait of Vyacheslav Koleichuk and Bulat Galeev was part of the installation of the exposition in St-Petersburg by Vyacheslav Loktev installations with light and sound in Leningrad by August Lanin ${ }^{1}$.

One of the key figures in this artistic process was the architect, designer, researcher, inventor, constructor and teacher Vyacheslav Fomich Koleichuk (1941-2018). This imaginary dialogue is covering some of the inventions of the artist, developing the traditions of Russian kinetic art, expanding the artistic space of modern design and architecture ${ }^{2}$.

Keywords: Vyacheslav Koleichuk, kinetic art in Russia, experiment in art, formal compositional systems, principles of form-creation, combinatorics, research of visual perception.

1. The history of kinetic art in Russia in the XX and XXI centuries is reflected in the exhibition catalog: "Laboratory of the Future. Kinetic Art in Russia ".-Saint-Petersburg: ANO "SH", Central Exhibition Hall "Manezh", 2020. 592 p., Ill.

2. An attempt to systematize the heritage of inventions (artistic, constructive, technical, conceptual) by Vyacheslav Koleichuk was the publication of the album "Vyacheslav Koleichuk: My Alphabet", prepared in 2012 by the Moscow State Art and Industry Academy named after SG Stroganov in connection with his personal exhibition in the gallery "Tunnel" of the Stroganov Academy. Curator: K. N. Gavrilin; installation: V.F. Koleichuk and A. V. Koleychuk; publication idea and design: A. N. Lavrentyev; layout of the edition: D. V. Koleychuk.

as an element of attraction that allowed visitors to take selphies with the legends of Russian kinetic art - is absolutely natural.

Both of them actively developed kinetic art, supported masters and young artists, created situations for the creation of something new: publications, competitions, exhibitions, conferences. Both led the 
"School-Festival of Kinetic Art" in Kazan, collaborated with the international magazine "Leonardo" 1 , where they published exploratory works belonging to the intersection of art, science and technology.

The presence of Koleichuk in this exhibition reveals his role as a kind of mediator between the classical avant-garde and the scientific and technical innovations of art, as a farseeing design theorist and an analyst of experimental creativity (his texts are widely included into the exposition in the form of comments) provokes many questions. He was doubting generally accepted items. Curiosity is a condition for inventing something new.

Let's try and act as curious spectators. Moreover, Koleichuk foresaw many questions and answered them in various articles, speeches, books ... The main thing is to find these answers.

In one of his talks, Koleichuk introduced an unusual notion "technological folklore". Why did the exhibition "Folk traditions in professional and amateur creativity", which Koleichuk compiled together with the art critic Vitaly Patsyukov, needed Rodchenko's models of spatial structures together with birch bark products? What was the idea behind the comparison of professional and amateur art, avant-garde art and folklore?

In 1985 in the exhibition hall near Kashirskaya subway station (Millionshchikova street) an exhibition "Folk traditions in professional and amateur art" was held. Here the following objects have been exhibited: wicker rugs and "wicker" collages of Koleichuk; geometric beanbags and a geometric pictures by Eduard Steinberg or photographic games with geometric mirrors by Francisco Infante, etc.

After this show, its exposition (almost unchanged) was transformed into the next one - "Geometry and Art" with the addition of material from the history of the Russian avant-garde art of the 1920s.

All the exhibits have been united by one end-toend geometric principle of shaping. In some works, their constructive basis was also repeated.

Koleichuk's answer in one of the articles in the scientific papers edition was as follows:

"In the history of culture, we come across end-toend almost unchanging symbols, forms, technologies,

1. Leonardo ISAST. (The International Society for the Arts, Sciences and Technology: International Society of Arts, Sciences and Technology). The publication, which unites a number of areas in the field of experimental scientific and artistic search, was founded in 1982. Chief Editor - Roger Malina, MIT Press. structural ideas. They lie outside the artist's personal creativity, they are constant and universal" 2 .

Koleichuk refers to them all kinds kinetic structures: the idea of a hinge like scissors, an ordinary wheel, fabric as a flexible structure. The very idea of identifying such "eternal" constructive principles is his original theoretical position, which followed from Koleichuk's own creative experience.

He made objects, constantly analyzed them and as a result produced generalizations, at the level of global laws of the formal structure of design objects, architecture, perception mechanisms.

He saw similarity of technology in an old birch bark braid and ultravanguard braided objects made from tubes of paint or photographic images, which he himself was doing. He saw the similarity of modeling approaches in Rodchenko's design and matryoshka dolls. Artistic technology leads to the idea of an object.

Folklore is traditionally understood as traditional ethnic basis of folk art. Like songs and dances, costumes. But this view deprives folklore of development. Although it is constantly changing. The jokes and anecdotes change, the clothes are changing, not haute couture, but the manner of dressing. Folklore can be also regarded as a part of professional architecture and design thinking. This is the subject of projects, competitions, values that seem worthy at the present moment to the professional community.

Behind these processes one can find the wholeness, organicness, naturalness of the birth of a thing, a design-object.

Where do ideas come from for artists, designers, architects?

Once in 1982, while working at VNIITE ${ }^{3}$, employees of the department of theory and history of design

2. "A concrete example of the sustainability of the ideas of mobility and transformation of products can be the principle of a hinge joint," wrote V. F. Koleichuk in the section "Transformation" of the book "Eksperiment v dizayne",- Moskva: Universistetskaya kniga, 2010, s. 104.

3. In 1978-1994 V. F. Koleichuk worked at the All-Union Scientific Research Institute of Technical Aesthetics. The period from the late 1970 s to the late 1980s was associated with the Department of Theory and History and History of Design, headed by Selim Omarovich Khan-Magomedov, in fact the founder of the scientific school for the study of the Russian avant-garde in design and architecture. In the department under the leadership of Koleichuk, a group of "artistic problems of form-creation" was created. Conferences and seminars were regularly held, works and collections were published, articles were published in the journal "Technical Aesthetics". Part of the research and educational activities 


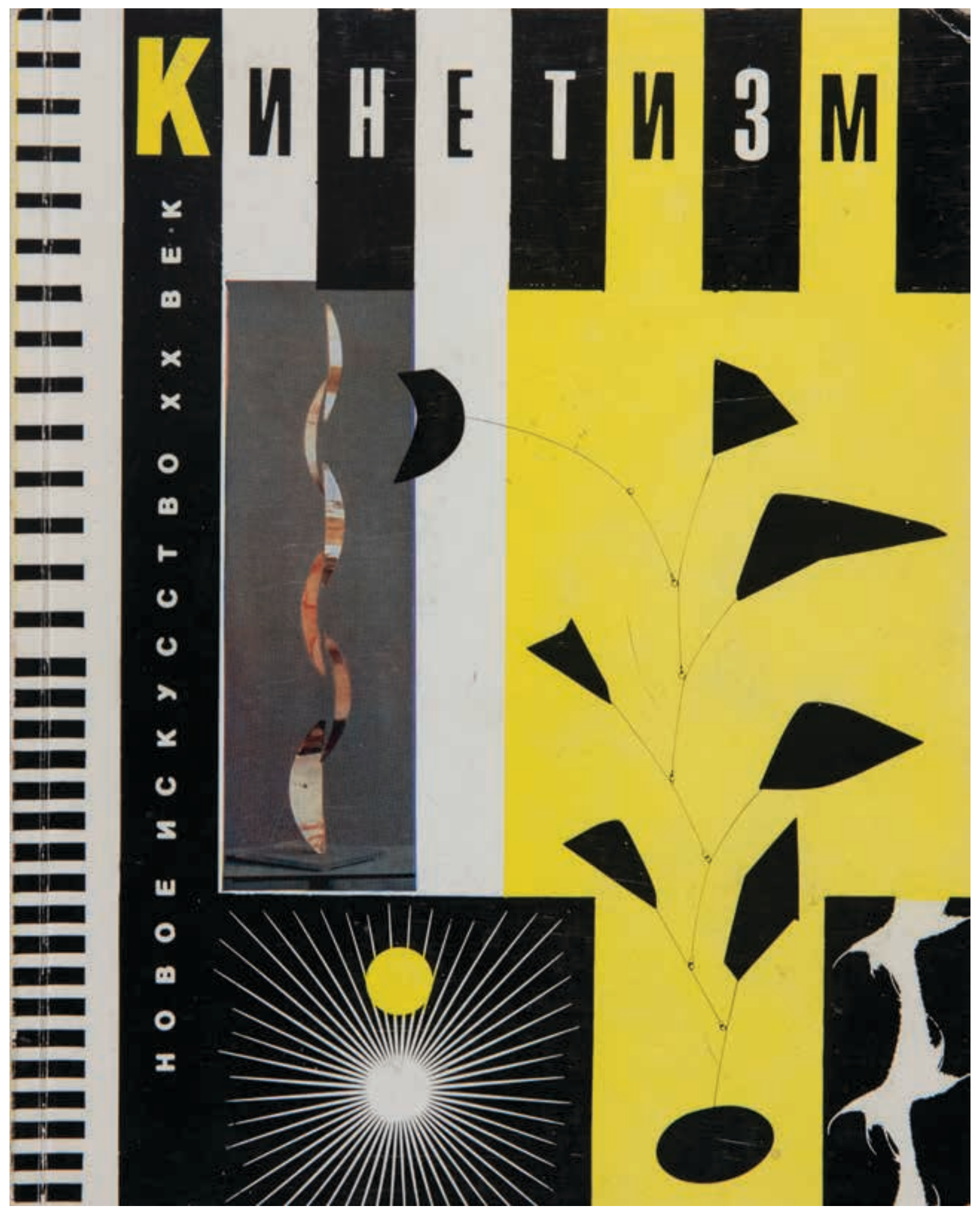

IIl. 2. Vyacheslav Koleichuk. Kineticism. Book cover. - Moscow, Galart, 1994

were sent to work at the collective farm in the Ruzsky district of the Moscow region. At lunchtime, we came across a graveyard of rusty agricultural machin-

of this group have been the annual scientific and practical seminars for designers "Experiment in Design", which have been held annually since 1984, which by and large can be considered a school of kinetic art. ery. All these former buses, potato diggers and plows were perceived as material for compositions and fragments of some kind of extraterrestrial aggregates. Three years later, the same feeling will arise again after watching Georgy Danelia's film "Kin-Dza-Dza".

The objective world of an unknown, very distant and dull planet was created by Koleichuk using 
the technique of assemblage. Real water taps and pipes, gears, handles, parts from metal beds were turned into movable objects of an unfamiliar civilization: "transclucators" (annihilators), "gravicappu" (energy concentrate for interstellar flights) and other outlandish things - weapons, musical instruments, money. No paper or plywood props - everything is extremely honest, weighty, assembled on cogs from rusty or in places worn out, aged metal.

Any situation can give birth to art, an artist's gesture. This is probably the most reckless occupation - to make art out of something that no one perceives as such.

In the experimental "Koleichuk's laboratory", his workshop, it happened just like that.

A whole direction of form-creation based on flares: "stereography", "svetoglikostereotectonics" arose after a careful study of an aluminum plate which Koleichuk polished with a drill and which suddenly fell down. His tenacious gaze noticed an illusory hovering cloud of light above this plate.

It turned out that scratched metal plates can give birth to spatial illusions of flares. These illusions are created by the lace of these differently turned circles and arcs of scratches. The "Koleichuk effect" was recorded in one of the messages at a scientific seminar at VNIITE and was patented.

What is "Light stereography", the area in which the duality of the work of art has manifested itself - is it outside us and at the same time inside us? Can Koleichuk be regarded as the inventor of visual creativity technologies?

"Hand-made holography, light-sphere tectonics, line stereography, etc. - this is an incomplete list of definitions of the new technology of shaping. At the first moment, when I formulated the principle itself and tested it practically, I experienced an intellectual shock - it turns out that it is so simple to engrave metal with your hands, you can create spatial compositions, illuminating the engraving with light (a point source), as in holography.

I was so much surprised that he wrote a text about his surprise and state at the time of the invention of a new graphic technique.

The structure of one or another stereo object is encoded by a system of ring lines on glass, plastic or metal. By illuminating the raster image with light, we get a glare system. Each eye sees its own glare pattern, as in a stereo pair. Merging into a mono-image, a stereo image is created in the spectator observation system. But that's not all. In stereography, you can look at an object from different sides, rotate it. There is another sign of space - perspective. Optical perspective. The effect of spatiality is so strong that spectators, especially children, will be tempted to touch the invention with their hands, but, alas, it is a phantom, an illusion. A good incentive for the viewer to think about virtual reality" 4 .

In the patent application, Koleichuk wrote:

"The proposed method for creating stereo images is based on light-reflective coding of each point of a stereo image and in this sense can be called a quasiholographic principle. It does not require special devices for observation.

The essence of the proposed method for recording stereo images consists in the oriented reflection of light from the mirror surface, mainly linear elements of different curvature and orientation on the image plane. In this case, the carrier of the oriented reflection can be a risk on glass, plastic, metal, a layer of fat or a mirror-like hemispherical or toroidal object" ${ }^{5}$.

Vacheslav Koleichuk's experiments and objects were always born out of life, from the simplest and most childish question: why?

Someone walks by or waits for an explanation from others.

Someone has been asking themselves questions and looking for answers all their lives.

Why do we perceive separate elements of the raster pattern from a close distance, and from a great distance they merge into a common gray spot?

What is the minimum number of connections in a stable tensegrity structure?

What makes us perceive some images and pictures as reflected in a mirror, and others as refracted through a glass prism?

Why does our artificial environment - buildings, streets, interiors, furniture - replicate predominantly rectangular coordinate system, a rectangular grid?

Why do we see this way and not another?

Koleichuk constantly questioned the generally accepted.

Among such common misconceptions, he attributed the attitude to a number of paradoxical graphic images known as the "Necker Cube" or "Penrose Triangle", which were considered only topological abstractions and not real physical models.

4. Here and below, without specifying the source, the words of V.F. Koleychuk, his real answers to the questions asked by the author of the article in 2017 are quoted.

5. V. Koleichuk. Method for creating stereo images. Description for the patent office. 1994 


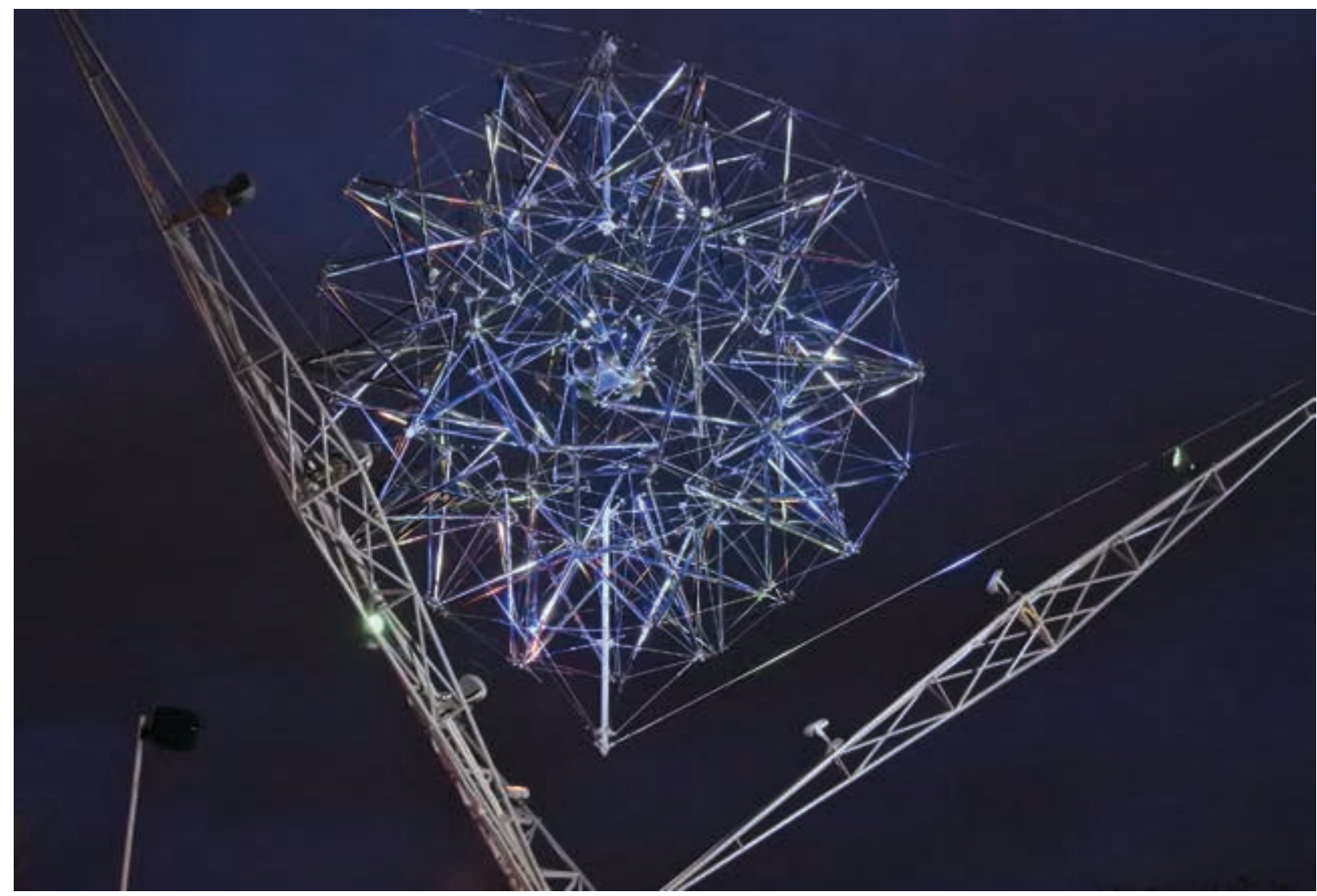

IIl. 3. Vyacheslav Koleichuk. Atom. Light-kinetic installation. 1967. Renovated in 2018, Garage

Speaking once at the Center for Contemporary Art in Moscow in 2005, Koleichuk mentioned that the very name of some graphic compositions and structures as "impossible" objects provoked for him the creation of these objects in real three-dimensional space. He said then that he had spoiled his perception of these objects.

What led to the research, the aspiration for the new experience, the proof of the "possibility" of the "impossible": an accident or an internal need? What gives the strength to bring the undertaken to the end? Is experience exhausted, or does the author return to each of his inventions from time to time?

"In the late 1960s, I got carried away with the "impossible "objects invented by the Penrose, or rather their famous graphic triangle, began to study psychological literature in the field of visual perception. Illusions, paradoxes and phenomena of our perception of the surrounding world have interested and carried away for life. I wanted to create three-dimensional models in spite of the claims that they cannot exist. $\langle\ldots>$ It is also true that having created a threedimensional model of the "Penrose triangle", and not even one, I lost my intellectual illusion, but acquired new principles of shaping, which I implemented in the "Living Line".

It was a series of graphic images such as "Necker Cube", "Penrose Triangle", "Trident". From the point of view of ordinary visual experience, they were "impossible" - the inner space flowed into the outer space and vice versa. One of the publications about these models in the Izvestia newspaper was titled: "The artist who built a triangle, in which all angles are rectangular." It was possible to build a threedimensional model, as it turned into a kind of spatial imagination task. Build the missing object projection based on the other two.

The bars that form the sides of the triangle were made s-shaped.

(The Japanese graphic designer Shigeo Fukuda came to the same decision, modeling in space "impossible" graphic objects "Penrose Triangle", figures by Oscar Ruthersward or Escher's drawings for the "Visual trick" exhibitions in Tokyo in the 1980s). Being at a point equidistant from all angles, the viewer sees all these bends straightened, the deformation disappears, flattens.

The volume under certain conditions of perception is reduced to a flat image. This, in fact, was the basis of Koleichuk's composition "Living Line". 
A dark blue colored metal bar curved in space on a white background was perceived as a line lying in one plane. The rotation of the bar created the illusion of a line wriggling before our eyes.

Once Koleichuk was looking at a piece of raster ornament made up of black and white squares of the same size from a close and distant distance for a long time. Then it occurred to him to glue the letter " $T$ " cut from a raster with a larger pattern over a square made up of small cells of the raster. At close range, the borders of the letters were readable due to the size. From far away - everything merged into one gray square. This is a demonstration of the optical effect of "equal-weighted lightness", as Koleichuk called it.

What prompted these experiments with raster images: a thought experiment or "concern" about facilitating the fate of human visual perception in an environment saturated with visual information? Does it have anything to do with research on raster structures, the graphic heritage left by op-art?

"All the texts are written or printed on a plane surface. We see them because of the difference in the lightness of the letters and the background. Black letter on white background, white on black or gray, etc. You can make it so that the integral lightness of the letter and the background will be the same, and information will be transmitted due to the difference in the size of the raster or its orientation in the image field. Everyone has seen a checkerboard - this is an example of a surface with equal lightness: $50 \%$ white, $50 \%$ black, in general it is gray when viewed from a great distance. One of my works is called "the gray square".

In the well-known art-trend of the second half of the twentieth century "op-art" (optical art), specially designed graphic linear structures are used, which cause the effects of vibration, movement, color in the human visual perception system, while remaining static and monochrome. As studies by Viacheslav Koleichuk have proved, in the viewer's perception system, there exists interrelation between the visual stimulus (an objective graphic structure) and the subjective visual effects caused by it. A kind of paradoxical situation arises - the illusion of movement in its real physical absence.

Experimenting with raster images, compositions in the style of "op-art" and well-known types of visual illusions, such as distortion of straight lines against a background of oblique or converging lines, Koleichuk discovered a special intermediate "visual field" between the retina and the central nervous system, in which visual processing takes place. Images exist here in the form of "light-grams" (this was a name for a combination of nervous impulses which Koleichuk suggested for the description of the phenomenon). It was a painstaking process of many hours observing the reactions of one's own visual system to various types of images, color and black and white, rasters with different direction of lines and sizes of elements.

He discovered that illusions are the results of mutual deformation of two systems of signals. First - signals received by the visual system from the perception of raster figures and the background. Second - signals emerging from the interaction of signals from an image with the perception system generated signals caused the same image. He called these signals of the second level "light-grams" (svetogrammy).

"The facts of the appearance of illusions of motion aftereffect or geometric illusions in the human visual system are widely known. On the basis of experimental studies, the following hypothesis of the origin of such illusions is put forward. A visible field [the field of perception and processing of visual images] was found in the human visual system, in which a distal stimulus, for example, a drawing of ten parallel lines, is presented not in the form of an adequate display, but as if in a form encoded with a certain pattern of light energy impulses. Each new graphic pattern has its own pattern of light impulses (by analogy with the device of holographic plates).

Moreover, a number of graphic structures - such as a herringbone fabric, a multibeam asterisk, circles on the water - cause a spontaneous, difficult to stabilize signal transfer in the visual system, which leads to vibrations in the elements of the pattern. Thus, the illusion of aftereffect is nothing but a reaction of the visual system to a definitely oriented transfer of signals in the light-gram. And the illusions of vibrations of lines in the listed figures are contained in the mechanism of interaction of a real figure with the multidirectional movement of signals in the light-gram" 6 .

"The detection in the visual system of accompanying signals, induced or provoked by raster figures and not coinciding in structure with them, makes it possible to conclude that there exists in the visual

6. Koleychuk V.F. Structural and energetic bases of illusion.- In the book: Scientific and technical progress and problems of the subject-spatial environment. M., 1982.- (Proceedings of conferences, meetings / VNIITE). P. 42-43

Koleychuk V.F. Strukturno-energeticheskiye osnovy vozniknoveniya illyuziy.- V kn.: Nauchno-tekhnicheskiy progress i problemy predmetno-prostranstvennoy sredy. M. 1982. - (Materialy konferentsiy, soveshchaniy/VNIITE). S.42-43 


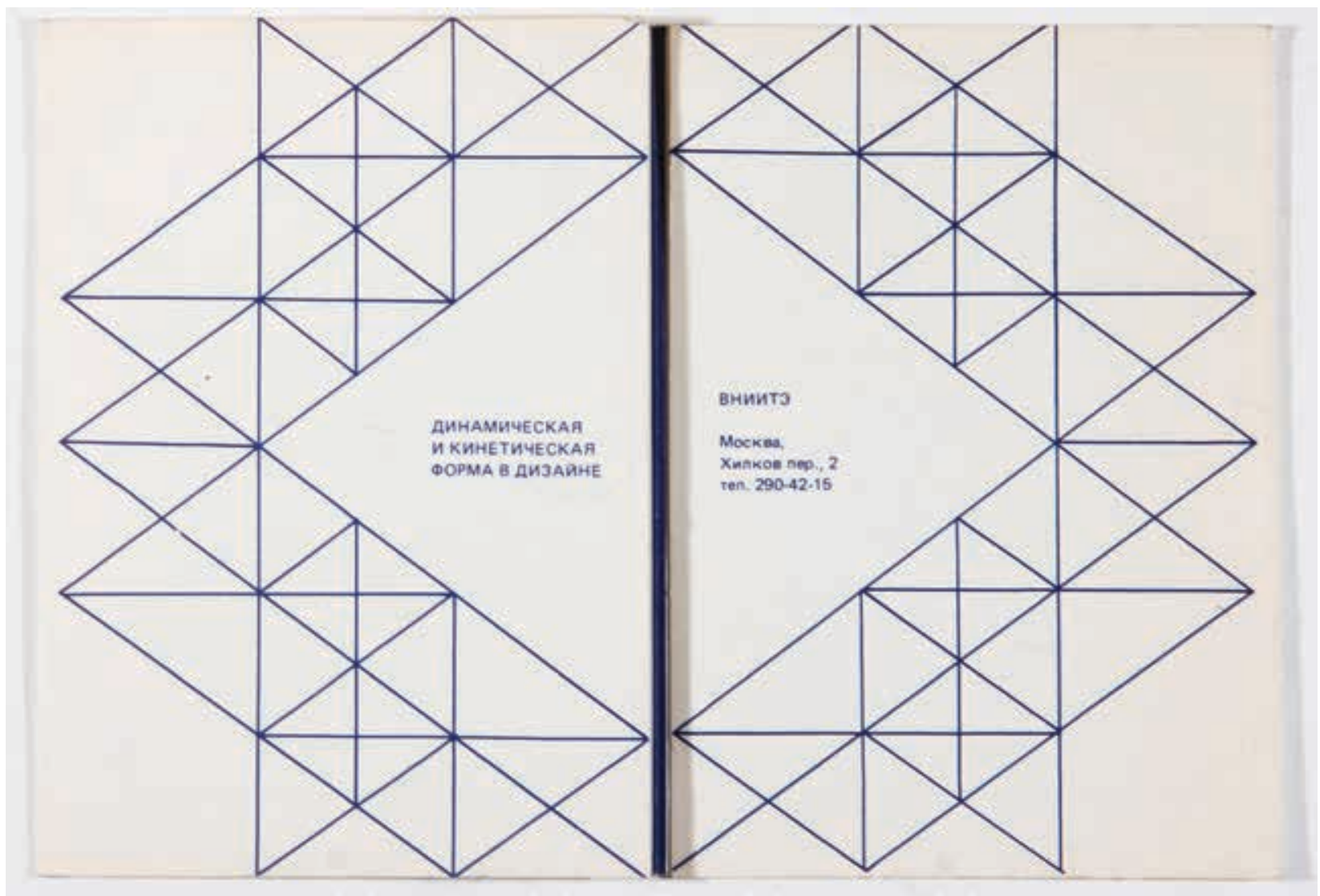

Ill. 4. Dynamic and kinetic form in design. The program of the scientific and practical seminar from the cycle "Experiment in Design". Moscow, VNIITE (Vsesoyuznyy nauchno-issledovatel'skiy institut tekhnicheskoy estetiki All-Union Scientific Research Institute of Technical Aesthetics). 1987

system, along with the image field or in it, a visible transfer field and interaction of light signals that are still unclear in structure.

"Visual information entering the brain consists of two complementary systems of visual information, the composition of the reticulated image and the light-gram, a kind of unobjective image code" 7 .

Koleichuk's "Gray Square" received another embodiment, this time theatrical. Anna Koleichuk, daughter of Vyacheslav Koleichuk, came up with the idea of creating a performance - a plastic action with an actor interacting with a dynamic projection of a changing raster composition. The composition was projected onto a double screen - that is, onto a translucent grid and onto a screen. The actor acted in the space between the two screens. Anna by that time had already made several videos and performances at the Theremin Center, which was the im-

7. Koleychuk V.F. Visual images of space. Experimental analysis experience. - In the book: Proceedings of VNIITE. Series Technical aesthetics No. 40. Space in the formation of the structure and image of the subject environment. M .: VNIITE, 1983.S. 57-71

Koleychuk V.F. Zritel'nyye obrazy prostranstva. Opyt eksperimental'nogo analiza. - V kn.: Trudy VNIITE. Seriya Tekhnicheskaya estetika № 40. Prostranstvo v formirovanii struktury i obraza predmetnoy sredy. M.: VNIITE, 1983. S.57-71 petus for the creation of the Total Theater in 1998, based on her father's 1967 project $^{8}$.

Andrey Topunov, a computer graphics designer, had a previously developed computer program "Fill Map Technology", similar in its visual characteristics to the works of Koleichuk with rectangular rasters. The program made it possible to revive static images, create a lot of options for spatial illusions due to raster elements of different scales. Anna, as a stage director of plasticity and light, at the end of rehearsals of the performance "Materi-ya" (Materia and me) on the stage of the House of Actor named after Yablochkina hurried to Topunov to his institute and set the timing and order of the images. Music was written by Stanislav Krejci.

"For wood and metal" voiced this action in the space of squares scattering or striving to a point, which, in combination with the plasticity of a living

8. The concept of "total theater" was published in the collection "Ritual. Theatre. Performance ". Materials of the transcripts of the laboratory of directors and artists of puppet theaters at hand. I. Uvarova. Moscow: March, 1999.

"Ritual. Teatr. Performens". Materialy stenogramm laboratorii rezhisserov i khudozhnikov teatrov kukol pod ruk. I. Uvarovoy. M.: Mart, 1999. 
actor, created a strong visual image of the birth and transformation of matter.

For about ten years, Koleichuk was engaged doing "self-collages" - compositions obtained by rearranging fragments cut out of the same image. He invented not only the technology, but also this term. What prevailed in this experience: intuition, play, mathematical and symmetric transformations? The simple operation of rearranging parts evokes strong spatial associations. Was this effect embedded in such a series from the start, or was it a "free app"?

"My article" Self-collage "was published in the journal" Interpressgraphic "in 1986, and the first work -" Cross "- in this technique was done in 1972. To formulate the principle of symmetry, studied the literature on symmetry, collage and art and at the same time experimented, gained visual experience. As a result, it resulted in the formulation: the minimum technology of positional transformations of symmetry within one, precisely one image.

Combinatorics mysteriously transforms into manipulation of elements (fragments of a complete image). Cutting out fragments of an image, rearranging them, rotating, etc., you can get images of glass, mirror and other objects in the tissue of the original image. The miracle of the emergence of new images occurs by changing the context of the background and figure."

Self-collage at the same time illustrated the provisions of Koleichuk on the theory of combinatorics and programmed shaping. (The theme of kineticism arises again: dynamics, permutations and variability!). For his self-collages, Koleichuk used banal reproductions of paintings by artists from the Tretyakov Gallery, postage stamps, postcards, photographs from calendars.

The meaning of "Self-collage" is that the artist manipulates fragments of a finished photographic image or photographic reproduction. He cuts squares and rectangles, triangles and circles, parallelograms and narrow stripes. Rearranging the elements, rotating them around the axis and allowing the viewer to see what actually was cut out or rearranged in the image. Everything seems to be simple and clear. But then strange things begin. From somewhere in the idyllic landscape, there are giant mirrors or icy transparent blocks, some kind of swollen spheres or lenses. The secret turns out to be simple and lies in the peculiarities of our visual perception.

With a minimal rearrangement of parts, when part of the image is only displaced horizontally or vertically, the viewer does not lose the impression of the original picture. His experience suggests that it is natural to refract rays in a transparent glass prism.

Rearranging the parts with rotation - when the landmarks of the top and bottom change and the image in the inverted part turns out to be in sharp contrast to the original background - it gives a different effect - mirrors. This is again related to our visual experience. We perceive a mirror as a mirror, not in isolation, by itself, but because it always gives a type of image contrasting with respect to the background.

It turned out that each image is fraught with its own possibilities of intervention and creation of phantom objects. Koleichuk did not actually build a giant glass block in the middle of a mountain valley. He deliberately used static images, the most trivial ones taken from wall calendars, to show the radical nature of the transformations taking place with the image. And then - every photographer can extend the pleasure of working on their own photography a little more.

What is art in this activity and is it even legitimate to talk about art here? What is art: technology or image? And what is the image of technology?

Koleichuk had several favorite exercises that he always gave to students. One of them is cutting the photo image into strips, their numbering, and then rearranging or sliding. In one case, symmetrical images are obtained, in the other - two clones of the same image with gaps. If you cut two images into strips - one horizontally and the other vertically and then weave something like a rug out of them - you get an interesting effect of flowing from one image to another.

In this simplest experiment, based on the compositions of Koleichuk, several patterns appear at once. First, there is a repetitive or changing rhythm of tissue structure. Secondly, the coding of the stripes involved in the weaving of such a "rug" programs the final result - the position of the image strips in the general composition. Third, due to the mutual interlacing of two images (some stripes are vertical, others are horizontal), a new visual field appears, which is different from the two original images.

Another, also uncomplicated, experience is the already mentioned "self-collage" - cutting photographic images in such a way that by rearranging the parts to get new shapes and objects. The exercises are simple, fast, and give instant results. The 


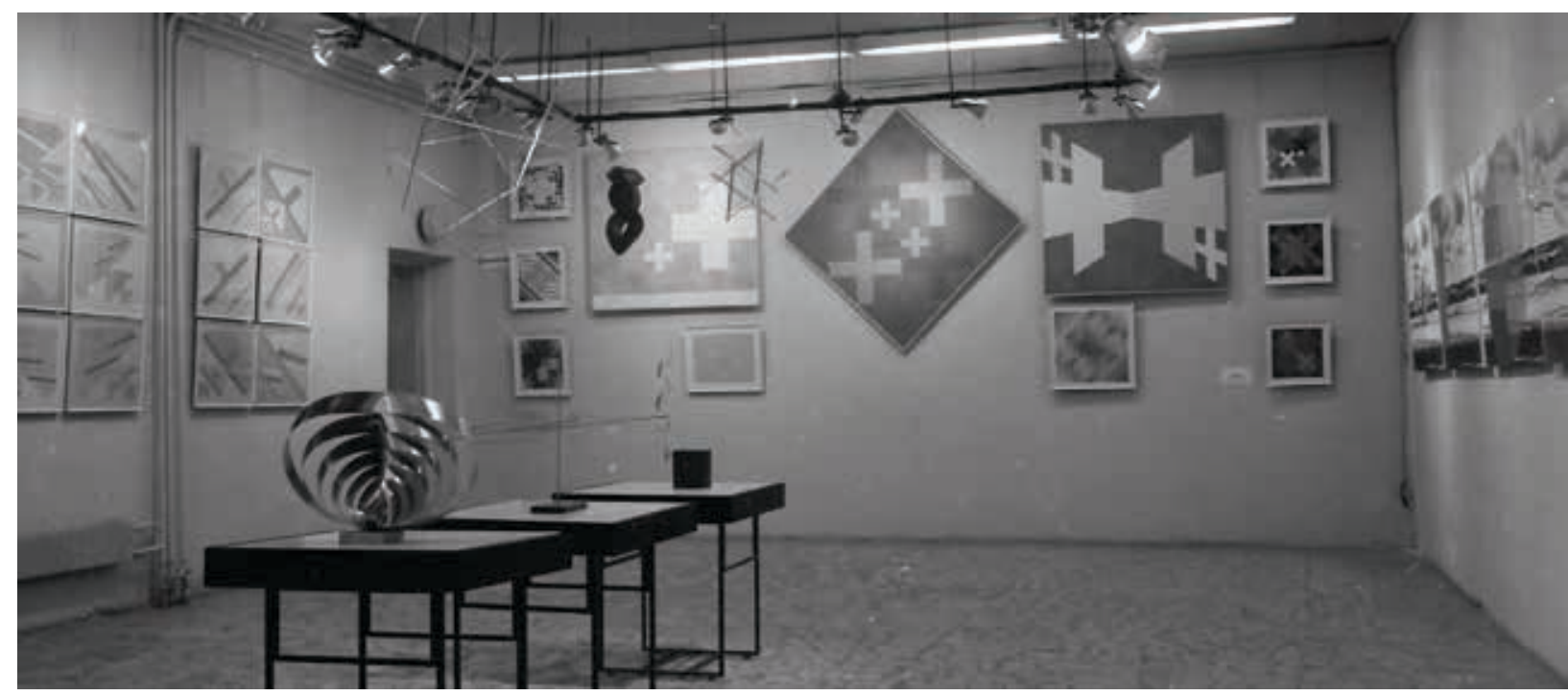

IIl. 5. Exhibition Color, Form, Space. 1978

very formulation of the assignment, its material equalize both people who have received a special art education and beginners, which is important for a rather diverse composition of students in modern universities.

Thanks to these exercises, the memory of invention and combinatorics remains. It is stored at the level of "muscle" memory, technological memory of operations. For an artist, however, this type of active, operational memory is the most important.

Regarding the technology, Koleichuk answered my question in 2017:

"Any medium in art has only its inherent visual properties. Of course, imitations are possible (remember the direction of photorealism, but this is an extreme case). The images and types of paper transformation are varied, but limited by the rules and properties of the paper itself. Rather, talk about the transformation of a plane or flat material. "

Koleichuk actually wrote the first book about kinetic art in Russian. He always worked simultaneously as an artist, designer, researcher and experimenter, scientist and theorist in the laboratory of architectural bionics at Sergei Lebedev, at the Institute of Theory and History of Architecture (TsNIIITIA) at Khan-Magomedov, or later at VNIITE. Until now, besides Koleychuk's book "Kinetism" - we have no other publication with a similar historical and creative panorama of works for researchers and students.

Did he consider his compositions to be part of the global art movement of the 1960s?

"In the 60s, the Movement group worked in Moscow, which was engaged in kinetic art, which was fashionable in the world. It was interesting to me, and I was in close contact with her and her leader -

\section{Nussberg."}

"1964-1965 is the beginning of cooperation with the Movement group, the first attempts to create which were undertaken back in 1962 by students of the Moscow secondary art school at the Surikov Institute and the group leader Lev Nusberg.

It was a period of storm and onslaught, an avalanche of new or previously inaccessible information from various fields of culture fell on society: philosophy, literature, cinema, theater, painting, design, architecture, whole scientific areas were rehabilitated - cybernetics, genetics, psychology. The intensification of intellectual activity, the search for new landmarks, impulses of artistic creativity inevitably led to an "interdisciplinary" exchange of information, to the erosion of the boundaries of legalized forms of art. Physicists and lyricists, cybernetics and art, scientific and technological revolution and artistic creation, technical aesthetics, cities of the future - the air itself was filled with these problems " 9 .

Against this background of the "thaw" (Ottepel), the expressive means of some types of art were integrated into others. Scientific, technical and artistic creativity, performing and visual arts were easily assimilated to each other. The project of "Total Theater" by Koleichuk also dates back to this time. The formal compositional basis, prototypes of many compositions by members of the "Movement" group were the spatial compositions of Naum Gabo - both strictly geometric and free contours wrapped in threads.

9. Koleychuk V.F. Kineticism.- Moscow: Galart, 1994, p. 48 Koleychuk V.F. Kinetizm. - Moskva: Galart, 1994, s.48 
As a group, the collective announced itself at an exhibition of kinetic art at the House of Architects in Leningrad in 1965. It was followed by an exhibition of kinetic art at the Club of the Institute of Atomic Energy in Moscow in 1966. Most likely, from that moment on, everything that Koleichuk produced, invented, built could be attributed to kinetic art. Including projects of mobile transforming architecture. In these models, made up of flat structural parts, by stretching a specially traced cable, "self-erection" (another author's term) of the future building occurs in a matter of seconds.

Do contemporary composers have musical analogies to the constructions on which Koleichuk played like musical instruments?

"Analogs to my musical instruments can be found in folklore (remember playing on a saw) and in professional orchestras (Italian tubular bells). Self-stressed bells are one thing, but the ovaloid is another.

Ovaloid - two oval-shaped duralumin discs, standing on the deck. There are three types of sound production: bow, percussion and various graters made of leather, glass and wood. The instrument has a rich timbre color and a wide sound range in terms of pitch and sound strength, so I call it a sound metal synthesizer."

It seemes that in Koleichuk's designs, the elements themselves were intended to extract sound: tubes of different lengths, freely suspended in the air, when struck, emit long-lasting sounds of different heights. Connecting wires are strings. In this case, the tubes can play the role of resonators.

Koleichuk's art is always a visual fusion of design, intuition and laboratory research. And also - his own research of history. He explained to his contemporaries the meaning of the first in the world and unique of its kind exhibition of spatial structures, held 100 years ago in Moscow, known in art history as the Second Spring Exhibition of OBMOKHU, (abbreviated as the Society of Young Artists). Alexander Rodchenko and Karl Ioganson joined the graduates of VKHUTEMAS - Vladimir and Georgy Stenberg and Konstantin Medunetsky. Since 2006, this exhibition in the form of a complete reconstruction in the hall of the State Tretyakov Gallery has become available to viewers.

When Koleichuk was engaged in the reconstruction of the OBMOKHU exhibition, he constantly questioned all available information. It turned out that at the OBMOKHU exhibition in 1921 there were one works by the Stenberg brothers, and in the 1970s, despite the external similarity, completely different author's reconstructions were created. It was usually believed that there was one number of works at the exhibition, but Koleichuk discovered another previously unknown object in the photograph. In the archive of the State Tretyakov Gallery, there was a huge, according to modern standards, glass negative plate $18 \times 24$, taken by an unknown photographer of the reproduction workshop of the Art Department of the People's Commissariat for Education in spring of 1921.

From this negative, probably for the first time since the 1920s, prints were made. Koleichuk not only found the real exhibition space in the house on Dmitrovka, the former Mikhailova salon, where the exhibition was located, but also found the plans of the building in the archive and managed to enter this room in a short moment of a change of owners and the beginning of renovations.

The reconstruction of this exhibition was done by Koleichuk with a full sense of artistic responsibility towards his predecessors. His son Dmitry and daughter Anna were closely involved in this process. It is important that both of them keep the knowledge of assembling and installing constructions of this type, especially tensegrity constructions tested by Karl Ioganson and developed by Koleichuk into a whole family of similar objects of different shapes, scales and use.

He formulated his addiction to the avant-garde and constructivists:

"I feel a spiritual kinship with A. Rodchenko, with his time. It was a good time - constructive. People are inventive, romantic. Such as Rodchenko "allowed" their creativity and we to invent, experiment, play with the imagination" ${ }^{10}$.

Vyacheslav Fomich Koleichuk died on the first day of Easter week, on the morning of April 9, 2018.

External signs of recognition and authority - Laureate of the 1994 State Prize, professor of Moscow Architectural Institute, academician, member of the National Academy of Design, member of creative unions of architects, artists and designers - all that provided an opportunity to share his research and experiments.

$\mathrm{He}$ is one of the founders of kinetic art in the USSR, a man who could turn a scientific discovery, a geometric drawing or a banal fact of everyday life into an object of art, break a stable stereotype of

10. V. Koleichuk. Record in the guestbook. February 3, 1993 Archive of A. Rodchenko and V. Stepanova

V. Koleychuk. Zapis' v knige otzyvov. 3 fevralya 1993 g. Arkhiv A. Rodchenko i V. Stepanovoy 


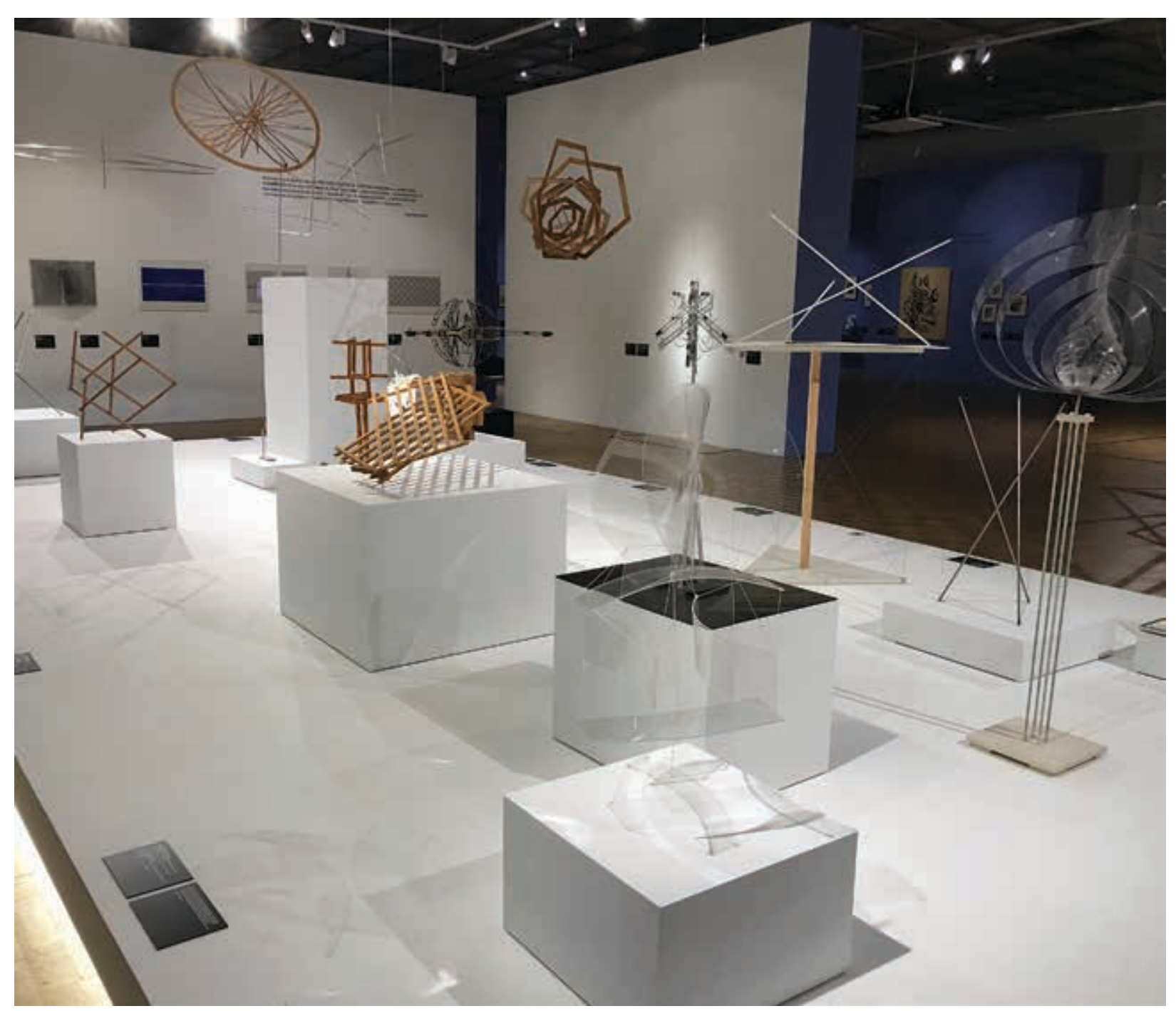

IIl. 6. Fragment of the exhibition "Laboratory of the Future. Kinetic Art in Russia". Tretyakov Gallery, 2021. Work by Vyacheslav Koleichuk (right) among the experimental constructions of Alexander Rodchenko and Karl loganson (Koleichuk's reconstructions)

perception (like the "impossibility" of constructing "impossible" figures), revealing to us the infinity of variants of structures around us the world.

He left behind amazing things: openwork lightweight metal structures in the Olympic Village in Moscow, objects for the summit in St. Petersburg, self-tensioned bells and other structures in Kolomna, park sculptures standing somewhere in Germany, he recreated an entire hall in the State Tretyakov Gallery predecessors of the art of high technology, the OBMOKHU exhibition of 1921, paying tribute to the inventions of Rodchenko, the Stenberg brothers, Ioganson and Medunetsky.

He left behind books and articles, projects and patterns, models and objects, photographs and films, TV shows.

He left ideas, technologies, ideas about the world. As he showed any principle he had found, he rejoiced at the opportunity to share it as a new creative puzzle. He was happy that he was able to understand and explain the law of obtaining volumetric structures from a plane, the connection of threads and rods in space, or the mechanism of the appearance of optical illusions.

As an actor or magician, he showed all these principles in action, inspiring young artists to constantly ask themselves "childish" questions: why do we see the world this way and not otherwise, what is optical movement and where does the "moire effect" come from, why do we predominate in our environment rectangular systems for designing and displaying space, how and into what the plane is transformed, how many cable-stayed ties in a tensegrity structure can be left to keep the system stable. He left us this irrepressible curiosity ... 


\section{REFERENCES}

1. Koleichuk, V. F. 2012. My alphabet, Moscow (in Russian)

2. Koleichuk, V. F. 1994. Kinetism. Moscow: Galart. (in Russian)

3. Laboratory of the future. Kinetic Art in Russia.- St. Petersburg: Central Exhibition Hall "Manezh", 2020. (in Russian)

4. Gluibizzi, A. 2021. Art and Design in 1960s New York. London, UK; New York, NY, USA: Anthem Press. DOI:10.2307/j.ctv1gbrrk9 (in English)

5. Topper, D., \& Holloway, J. 1980. Interrelationships between the Visual Arts, Science and Technology: A Bibliography. Leonardo, 13(1), 29-33. DOI:10.2307/1577916 (in English)

6. Applin, J., Spencer, C., \& Tobin, A. (Eds.). 2018. London Art Worlds: Mobile, Contingent, and Ephemeral
Networks, 1960-1980. University Park, Pennsylvania: Penn State University Press. DOI:10.5325/j.ctv14gp$4 \mathrm{cg}$ (in English)

7. Zinman, G. 2020. Making Images Move: Handmade Cinema and the Other Arts. Oakland, California: University of California Press. DOI:10.2307/j.ctvqr1bkx (in English)

8. George F. Flaherty. 2014. Responsive Eyes: Urban Logistics and Kinetic Environments for the 1968 Mexico City Olympics. Journal of the Society of Architectural Historians, 73(3), 372-397. DOI:10.1525/jsah.2014.73.3.372 (in English)

9. Galeyev, B. 1991. Musical-Kinetic Art in the USSR. Leonardo, 24(1), 41-47. DOI:10.2307/1575467 (in English) 


\section{ВЯЧЕСЛАВ КОЛЕЙЧУК КАК ДВИГАТЕЛЬ РУССКОГО КИНЕТИЗМА. ВООБРАЖАЕМЫЙ ДИАЛОГ HA BЫCTABKE}

Аннотация: В ГТГ проходит знаменательная выставка «Лаборатория будущего. Кинетическое искусство в России». Ее значение, влияние самого художественного феномена кинетического искусства на отечественное искусство XX и XXI века еще не до конца определены. Выставка акцентирует кинетическое искусство как один из центральных национальных трендов в экспериментальном художественном творчестве XX века, как своеобразную традицию.

С одной стороны, выставка была бы невозможна без участия творцов русского авангарда, основоположников абстрактного искусства, создателей первых отвлеченных скульптур и динамических конструкций: В.В. Кандинского, К.С. Малевича, Эль Лисицкого, В.Е. Татлина, А. М. Родченко. С другой стороны, важны и признанные мастера, изобретатели кинетизма в СССР в 1960е и 1970-е годы, творцы синтеза звука, цвета, формы, изображения и динамики: «Группа Движение» Льва Нусберга в Москве и «КБ Прометей» под руководством Булата Галеева в Казани, первая кинетическая конструкция на ВДНХ СССР Франциско Инфанте и динамическая установка «Атом» Вячеслава Колейчука, опыты с электронным звуком и акустикой Экспериментальной студии электронной музыки Евгения Мурзина Термен-центра, созданного Андреем Смирновым, космические проекты Вячеслава Локтева и светоди-

То, что композиции Вячеслава Колейчука появляются почти в каждом разделе открывшейся 14 февраля 2021 г. в ГТГ выставки «Лаборатория будущего. Кинетическое искусство в России» - не случайно.

То, что двойной фотопортрет Вячесеслава Колейчука и Булата Галеева участвовал в экспозиции в. Питере как элемент аттракциона, намические установки для Ленинграда Августа Ланина ${ }^{1}$. Одной из ключевых фигур этого художественного процесса был архитектор, дизайнер, исследователь, изобретатель, конструктор и педагог Вячеслав Фомич Колейчук (1941-2018). Воображаемый диалог охватывает лишь часть изобретений Колейчука, развивающих традиции русского кинетизма, расширяющими художественное пространство современного дизайна и архитектуры ${ }^{2}$.

Ключевые слова: Вячеслав Колейчук, кинетическое искусство в России, эксперимент в искусстве, формально-композиционные системы, принципы формообразования, комбинаторика, исследование зрительного восприятия.

1. История кинетического искусства в России в XX и XXI веке отражена в каталоге выставки: «Лаборатория будущего. Кинетическое искусство в России».-Санкт-Петербур: АНО «СХ», Центральный выставочный зал «Манеж», 2020. 592 с., ил.

2. Попыткой систематизировать огромный багаж изобретений (художественных, конструктивно-технических, концептуальных) Вячеслава Колейчука стало издание альбома «Вячеслав Колейчук: моя азбука», подготовленного в 2012 году МГХПА им. С. Г. Строганова в связи с его персональной выставке в галерее «Тоннель» Строгановской академии. Куратор: К.Н. Гаврилин; инсталляция: В.Ф. Колейчук и А. В. Колейчук; идея издания и дизайн: А. Н. Лаврентьев; верстка издания: Д.В. Колейчук.

позволявший посетителям сфотографироваться с легендами кинетизма - закономерно. Они оба двигали кинетическое искусство, поддерживали мастеров и молодых художников, создавали ситуации для рождения нового: публикации, конкурсы, выставки, конференции. Оба вели в Казани «Школу-фестиваль кинетического искусства», 
сотрудничали с международным журналом «Леонардо» ${ }^{1}$, где публиковали поисковые работы на стыке искусства, наук и технологий.

Присутствие Колейчука на выставке как своеобразного посредника между классическим авангардом и научно-техническими новациями искусства, точного в суждениях теоретика дизайна и аналитика экспериментального творчества (его тексты вплетены в ткань экспозиции в виде комментариев) провоцирует множество вопросов. Любопытство, сомнение в общепринятом условие изобретения нового.

Попробуем и мы выступить в роли любопытных зрителей. Тем более, что многие вопросы автор предвидел и в разных статьях, выступлениях, книгах на них ответил... Главное лишь найти эти ответы.

В одном из своих выступлений Колейчук ввел необычный термин «технологический фольклор». Для чего к выставке «Народные традиции в профессиональном и самодеятельном творчестве», которую Колейчук придумал вместе с искусствоведом Виталием Пацюковым, рядом с изделиями из бересты понадобились выставить и модели пространственных конструкций Родченко? В чем смысл сопоставлений профессионального и самодеятельного творчества, авангарда и фольклора?

В 1985 году в выставочном зале на Каширской (улица Миллионщикова) состоялась выставка «Народные традиции в профессиональном и самодеятельном творчестве». Тогда были выставлены следующие экспонаты: плетеные коврики и «плетеный» коллаж Колейчука; шаркунки из геометрических фигур и геометрическая картина Э. Штейнберга или игра с геометрическими зеркалами у Франциско Инфанте и т.д. После этой выставки почти без изменения эта экспозиция переросла в следующую - «Геометрия и искусство» с добавлением материала из истории русского художественного авангарда 20-х годов.

Все экспонаты объединял один сквозной геометрический принцип формообразования. В некоторых работах повторялась и их конструктивная основа.

1. Leonardo ISAST. (The International Society for the Arts, Sciences and Technology: Международное общество Искусств, наук и технологии). Издание, объединяющее целый ряд направлений в области экспериментального научно-художественного поиска, основано в 1982 году. Главный редактор - Роджер Малина, издательство MIT Press.
Ответ Колейчука в одной из статей в научном сборнике был следующий:

В истории культуры существуют сквозные почти неизменяющиеся символы, формы, технологии, структурные идеи. Они лежат за пределами личного творчества художника, они постоянны и универсальны... ${ }^{2}$

К ним Колейчук относил все кинетические структуры, идею шарнирного соединения по типу ножниц, обыкновенное колесо, ткань как гибкую структуру. Сама идея выделения таких «вечных» конструктивных принципов - оригинальное авторское теоретическое положение, вытекающее из собственного творческого опыта Колейчука. Он делал объекты, постоянно их анализирова и в итоге выдавал обобщения на уровне глобальных законов формального устройства объектов дизайна, архитектуры, механизмов восприятия.

Он увидел единство технологий в старинной плетенке из бересты и ультравангардных объектах-плетенках из тюбиков краски или фотоизображений, которыми сам занимался. Он увидел близость подходов моделирования в конструкции Родченко и матрешке. Технология художника, технология моделирования - ведет к рождению идеи вещи.

Фольклор традиционнно понимается как этническое начало в народном искусстве. Как песни и пляски, костюмы. Но такая точка зрения отказывает фольклору в праве на развитие. А он все время меняется, живет. Как меняются анекдоты, как меняется одежда, не высокая мода, а манера одеваться. Фольклор - часть и профессионального проектного архитектурного и дизайнерского мышления. Это тематика проектов, конкурсов, ценности, которые кажутся достойными в современном профессиональном сообществе.

За этими процессами стоит цельность, органичность, естественность рождения вещи.

Откуда вообще приходят идеи к художникам, дизайнерам, архитекторам?

Однажды в 1982 году, еще во времена работы во ВНИИТЭ ${ }^{3}$ сотрудников отдела теории и истории

2. «Конкретным примером устойчивости идей мобильности и трансформации изделий может служить принцип шарнирного соединения», - писал В.Ф. Колейчук в разделе «Трансформация» в изджании «Эксперимент в дизайне»,- Москва: Универсистетская книга, 2010, с. 104.

3. В 1978-1994 годах В.Ф. Колейчук работал во Всесоюзном научно-исследоваттельском институте технической эстетики. Период с конца 1970-х до конца 1980-х был связан с отделом теории и истории и истории дизайна, которым руководил Селим Омаровичч Хан-Магомедов, фактически 
дизайна отправили на картошку в Рузский район Московской области. В обеденный перерыв мы набрели на кладбище ржавой сельхозтехники. Все эти бывшие автобусы, картофелекопалки и плуги воспринимались как материал для композиций и обломки каких-то внеземных агрегатов. Через три года это же ощущение возникнет снова после просмотра фильма Георгия Данелия «Кин-Дза-Дза». Предметный мир неведомой, очень далекой и унылой планеты был создан Колейчуком в технике ассамбляжа. Настоящие водопроводные краны и трубы, зубчатки, рукоятки, детали от металлических кроватей превращались в подвижные объекты незнакомой цивилизации: «трансклюкаторы» (аннигиляторы), «гравицаппу» (концентрат энергии для межзвездных перелетов) и прочие диковинные штуки - оружие, музыкальные инструменты, деньги. Никакой бумажной или фанерной бутафории - все предельно честно, весомо, собрано на винтиках из ржавого или местами потертого, постаревшего металла.

Из любой ситуации может родиться искусство, жест художника. Это, наверное, самое азартное занятие - делать искусство из того, что никто не воспринимает таковым.

В экспериментальной «лаборатории Колейчука», его мастерсикой, это происходило именно так.

Целое направление формообразования на основе бликов: «стереография», «светобликостереотектоника» возникло после тщательного изучения упавшей на пол алюминиевой пластинки, которую Колейчук полировал при помощи дрели. Его цепкий и взгляд заметил иллюзорно возникшее парящее облако света над этой пластинкой.

Оказалось, что на рождение пространственных иллюзий при разглядывании процарапанных металлических пластин влияет именно кружево этих по-разному повернутых к свету окружностей и дуг царапин. «Эффект Колейчука» был зафиксирован в одном из сообщений на научном семинаре во ВНИИТЭ и запатентован.

основатель научной школы изучения русского авангарда в дизайне и архитектуре. В отделе под руководством Колейчука была создана группа «художественных проблем формообразования». Регулярно проводились конференции и семинары, издавались труды, сборники, печатались статьи в журнаде «Техническая эстетика». Часть научноисследовательской и образовательной деятельности этой группы стали ежегодно проводившиеся с 1984 года научно-практические семинары для дизайнеров «Эксперимент в дизайне», которые по большому счету можно считать школой кинетизма.
Что такое «Светостереографика», область в которой проявилась двойственность произведения искусства - оно находится вне нас и одновременно внутри нас? Можно ли назвать Колейчука изобретателем технологий визуального творчества?

«Рукодельная голография, светосфера, тектоника, итриховая стереографика и т.n. - вот неполный перечень определений новой технологии формообразования. В первый момент, когда я сформулировал сам принцип и проверил его практически, я испытал интеллектуальный шок - оказывается, так просто руками, гравируя металл, можно создавать пространственные композиции, освещая гравировку светом (точечным источником), как в голографии. Так удивился, что написал текст о том своем удивлении и состоянии в момент изобретения новой графической техники.

Структура того или иного стереообъекта кодируется системой кольчевых итрихов на стекле, пластике или металле. Освещая рисунок растра светом, мы получаем систему бликов. Каждый глаз видит свой рисунок бликов, как в стереопаре. Сливаясь в монообраз, в зрительной системе наблюдения создается стереообраз. Но это не все. В стереографике можно оглядывать объект с разных сторон, вращать его. Имеется и еще один признак пространства перспектива. Оптическая перспектива. Эффект пространственности настолько сильный, что зрители, особенно дети, норовят потрогать руками изобретение, но, увы - это фантом, иллюзия. Хороший стимул для зрителя призадуматься о виртуальной реальности» ${ }^{4}$.

В патентной заявке Колейчук писал:

«Предлагаемый способ создания стереоизображений основан на светобликовом кодировании каждой точки стереоизображения и в этом смысле может быть назван квазиголографическим принципом. Он не требует для рассмотрения специальных устройств.

Сущность предлагаемого способа записи стереоизображений состоит в ориентированном отражении света от зеркальных, преимущественно линейчатых, элементов различной кривизны и ориентации на плоскости изображения. При этом носителем ориентированно-

4. Здесь и далее без указания источника приведены слова В.Ф. Колейчука, его реальные ответы на заданные в 2017 году автором статьи вопросы. 
го отражения может явиться риска на стекле, пластмассе, металле, слой жира или зеркальный полусферический или торообразный объект» 5 .

Опыты и объекты Вячеслава Колейчука всегда рождались из жизни, из самого простого и детского вопроса: почему?

Кто-то проходит мимо или дожидается объяснения от других.

Кто-то всю жизнь задает себе вопросы и ищет ответы.

Почему с близкого расстояния мы воспринимаем отдельные элементы растрового узора, а с большого расстояния они сливаются в общее серое пятно?

Каково минимальное количество связей в стабильной самонапряженной конструкции?

Что заставляет воспринимать нас одни изображения и картинки как отраженные в зеркале, а другие - как преломленные через стеклянную призму?

Почему наше искусственное окружение - здания, планировка улиц, интерьеры, мебель - все это подчиняется преимущественно прямоугольной системе координат, прямоугольной сетке?

Почему мы видим так, а не иначе?

Колейчук постоянно ставил под сомнение общепринятое.

К числу таких общепринятых заблуждений он относил отношение к целому ряду парадоксальных графических изображений, известных как «Куб Неккера» или «Треугольник Пенроуза», считавшихся лишь топологическими абстракциями.

Выступая однажды в Центре Современного Искусства в Москве в 2005 году, Колейчук обмолвился, что само название некоторых графических композиций и структур как «невозможных» объектов спровоцировало создание этих объектов в реальном трехмерном пространстве. Он сказал тогда, что испортил себе восприятие этих объектов.

Что же привело к поиску, выбору очередного опыта, доказательства «возможности» «невозможного»: случай или внутренняя потребность? Что придает силы довести затеянное до конца? Бывает ли опыт исчерпанным, или к каждому из своих изобретений автор время от времени возвращается?

«В конце 1960-х годов я увлекся «невозможными» объектами, придуманными Пенроузами,

5. В. Колейчук. Способ создания стереоизображений. Описание для патентного бюро. 1994 вернее их известным графическим треугольником, начал изучать психологическую литературу в области зрительного восприятия. Иллюзии, парадоксы и феномены нашего восприятия окружающего мира заинтересовали и увлекли на всю жизнь. Захотелось создать трехмерные модели в пику утверждениям, что их не может быть. <... > Верно и то, что создав трехмерную модель «треугольника Пенроуза», и даже не одну, я лишился интеллектуальной иллюзии, но зато приобрел новые принципы формообразования, которые реализовал в работе «Живая линия».

Речь шла о серии графических изображений типа «Куб Неккера», «Треугольник Пенроуза», «Трезубец». С точки зрения обычного зрительного опыта они были «невозможны» - внутреннее пространство перетекало во внешнее и наоборот. Одна из публикаций по поводу этих моделей в газете «Известия» называлась: «Художник, который построил треугольник, у которого все углы - прямые». Построить трехмерную модель оказалось возможным, поскольку это превратилось в своего рода задачу на пространственное воображение. Построить недостающую проекцию объекта на основе двух других. Бруски, составляющие стороны треугольника были выполнены s-образными.

(К такому же решению пришел и японский дизайнер-график Сигео Фукуда, моделируя в пространстве «невозможные» графические объекты «Треугольник Пенроуза», фигуры Оскара Рутерсварда или рисунки Эшера для выставок «Visual trick» в Токио в 1980-е годы). Находясь в равноудаленной от всех углов точке, зритель видит все эти изгибы выправленными, деформация скрадывается, уплощается. Объем при определенных условиях восприятия редуцируется в плоское изображение. На этом собственно и была основана композиция Колейчука «Живая линия». Окрашенный темно синим, изогнутый в пространстве металлический пруток на белом фоне воспринимался как линия лежащая в одной плоскости. Вращение прутка создавало иллюзию извивающейся на наших глазах линии.

Однажды Колейчук долго рассматривал с близкого и далекого расстояния кусочек растрового орнамента, составленного из черных и белых квадратов одинакового размера. Потом ему пришло в голову наклеить поверх квадрата, составленного из мелких ячеек растра, букву «Т», вырезанную из растра с более крупным рисунком. С близкого 
расстояния границы буквы читались за счет размера. С далекого - все сливалось в один серый квадрат. Это и есть демонстрация оптического эффекта «равновзвешенной светлоты», как назвал его Колейчук.

Что подтолкнуло к этим опытам с растровыми изображениями: мысленный эксперимент или «забота» об облегчении участи зрительного восприятия человека в перенасыщенной визуальной информацией среде? Связано ли это вообще с исследованиями растровых структур, того графического наследия, которое оставил оп-арт?

"Все тексты пишутся или печатаются на плоскости. Мы их видим из-за разницы светлоты букв и фона. Черная буква на белом фоне, белая на черном или сером и т. д. Можно сделать так, что интегральная светлота буквы и фона будет одинаковой, а информация будет передаваться за счет разницы в размерах растра или его ориентации в поле изображения. Все видели шахматную доску - это пример поверхности с равновзвешенной светлотой: $50 \%$ белого, $50 \%$ черного, в челом, - это серое, если рассматривать его на большом расстоянии. Одна из моих работ так и называется «серый квадрат».

В известном направлении искусства второй половины XX века «оп-арт» (оптическое искусство) используются специально сконструированные графические линеарные структуры, которые вызывают в зрительной системе человека эффекты вибрации, движения, цвета, сами при этом оставаясь статичными и монохромными. Дело в том, что как показали исследования В. Колейчука, в восприятии зрителя образ складывается из изображения объективной графической структуры и вызванных ею субъективных визуальных эффектов. Возникает своего рода парадоксальная ситуация - иллюзия движения при его реальном физическом отсутствии.

Занимаясь экспериментами с растровыми изображения, композициями в стиле «оп-арт» и известными типами иллюзий зрения, вроде искажения прямых линий на фоне из наклонных или сходящихся линий, Колейчук обнаружил особое промежуточное зрительное поле между сетчаткой и центральной нервной системой, в котором происходит переработка зрительных образов, существующих в форме «светограмм». Это был кропотливый процесс многочасового наблюдения за реакциями своей собственной зрительной системы на различные типы изображений, цветных и черно-белых, растров с различным направлением линий и размеров элементов. Он открыл, что иллюзии - это и есть взаимная деформация двух систем сигналов, получаемых зрительной системой от восприятия растровых фигур и фона, от взаимодействия сигналов от изображения с порождаемой этим же изображением системой сигналов уже в зрительной. Эти сигналы второго уровня он назвал «светограммами».

«Широко известны факты появления иллюзий последействия движения или геометрических иллюзий в зрительной системе человека. На основе экспериментальных исследований выдвигается следующая гипотеза происхождения таких иллюзий. В зрительной системе человека обнаружено видимое поле [поле восприятия и переработки зрительных образов], в котором дистальный стимул, например, рисунок из десятка параллельных линий, представлен не в виде адекватного отображения, а как бы в закодированном определенным рисунком световых энергетических импульсов виде. Каждому новому графическому рисунку соответствует свой рисунок светоимпульсов (по аналогии с устройством голографических пластинок).

Более того, ряд графических структур типа ткани в елочку, многолучевой звездочки, кругов на воде - вызывает в зрительной системе спонтанный, трудно стабилизирующийся перенос сигналов, что приводит к возникновению вибраций в элементах рисунка. Таким образом, иллюзии последействия есть не что иное, как реакция зрительной системы на определенно ориентированный перенос сигналов в светограмме. А иллюзии вибраций линий в перечисленных рисунках заключены в механизме взаимодействия реального рисунка с разнонаправленным движением сигналов в светограмме» ${ }^{6}$

"Обнаружение в зрительной системе сигналов сопровождения, наведенных или спровоцированных растровыми фигурами и не совпадающих по структуре с ними, позволяет сделать вывод о существовании в зрительной системе, наряду с полем изображения или в нем, еще неясного по устройству видимого поля переноса и взаимодействия светосигналов.

6. Колейчук В.Ф. Структурно-энергетические основы возникновения иллюзий. - В кн.: Научно-технический прогресс и проблемы предметно-пространственной среды. М., 1982. - (Материалы конференций, совещаний/ВНИИТЭ). С. $42-43$ 
«Зрительная информация, поступающая в мозг, состоит из двух взаимодополняющих систем визуальной информации, композиции сетчатого изображения и светограммы, некоего распредмеченного кода изображения» ${ }^{\text {. }}$

«Серый квадрат» Колейчука получил и еще одно воплощение, на этот раз театральное. У Анны Колейчук, дочери Вячеслава Колейчука, родилась идея создания перформенса - пластического действия с актером, взаимодействующим с динамической проекцией меняющейся растровой композиции. Композиция проецировалась на двойной экран - то есть на полупрозрачную сетку и на экран. Актер действовал в пространстве между этими двумя экранами. Анна к тому моменту уже сделала несколько видеофильмов и перформенсов на базе Термен-центра, что и послужило импульсом к созданию в 1998 году Тотального театра, опираясь на проект отца 1967 года 8 .

У Андрея Топунова, дизайнера, занимающегося компьютерной графикой, была разработанная ранее компьютерная программа «Технология карт заполнения», аналогичная по своим визуальным характеристикам работам Колейчука с прямоугольными растрами. Программа позволяла оживить статичные изображения, создать массу вариантов пространственных иллюзий за счет разномасштабных растровых элементов. Анна, как постановщик пластики и света, по окончании репетиций перформенса «Матер-и-я» на сцене Дома актера им. Яблочкиной спешила к Топунову в институт и задавала хронометраж и порядок изображений. Музыка Станислава Крейчи «Для дерева и металла» озвучивала это действие в пространстве разбегающихся или стремящиеся в точку квадратов, что в сочетании с пластикой живого актера создавали сильный визуальный образ рождения и трансформации материи.

Около десяти лет Колейчук занимался «самоколлажами» - композициями, полученными путем перестановки вырезанных из одного и того же изображения фрагментов, попутно придумав не только технологию, но и этот термин. Что преобладало в этом опыте: интуиция, игра,

7. Колейчук В.Ф. Зрительные образы пространства. Опыт экспериментального анализа.-В кн.: Труды ВНИИТЭ. Серия Техническая эстетика № 40. Пространство в формировании структуры и образа предметной среды. М.: ВНИИТЭ, 1983. С. $57-71$

8. Концепция «тотального театра» была опубликована в сборнике «Ритуал. Театр. Перформенс». Материалы стенограмм лаборатории режиссеров и художников театров кукол под рук. И. Уваровой. М.: Март, 1999. математические и симметрические преобразования? Простая операция перестановки частей вызывает сильные пространственнообразные ассоциации. Закладывался ли этот эффект в подобную серию изначально, или это оказалось «бесплатное приложение»?

«Моя статья "Самоколлаж» была напечатана в журнале "Интерпрессграфик» в 1986 году, а первая работа — «Крест» - в этой технике была сделана в 1972 г. Чтобы сформулировать принцип «самоколлажа» пришлось хорошо поработать: говорил с математиками, специалистами по симметрии, изучал литературу по симметрии, коллажу и искусству и одновременно экспериментировал, набирался визуального опыта. В итоге он вылился в формулировку: минимальная технология позиционных преобразований симметрии в пределах одного, именно одного изображения. Комбинаторика таинственным образом перевоплощается в манипуляцию элементами (фрагментами целостного изображения). Вырезая фрагменты изображения, переставляя их местами, поворачивая и т. п., можно получить изображения стеклянных, зеркальных и других объектов в ткани исходного изображения. Чудо возникновения новых образов происходит за счет смены контекста фона и фигуры».

Самоколлаж одновременно иллюстрировал положений Колейчука по теории комбинаторики и программированного формообразования. (Снова возникает тема кинетизма: динамики, перестановок и вариативности!). Для своих самоколлажей Колейчук использовал банальные репродукции картин художников из Третьяковской галереи, почтовые марки, открытки, фотографии из календарей.

Смысл «Самоколлажа» в том, что художник манипулирует фрагментами готового фотоизображения или фоторепродукции. Он вырезает квадраты и прямоугольники, треугольники и круги, параллелограммы и узкие полосы. Перестановка элементов, поворот их вокруг оси и позволяют зрителю видеть, что же собственно в изображении было вырезано или каким-то образом переставлено. Вроде бы все просто и понятно. Но дальше начинаются странные вещи. Откуда-то в идиллическом пейзаже оказываются гигантские зеркала или ледяные прозрачные глыбы, какие-то вспученные сферы или линзы. Секрет оказывается прост и заключен в особенностях нашего зрительного восприятия. 
При минимальной перестановке частей, когда часть изображения лишь смещена по горизонтали или вертикали, зритель не теряет впечатления от исходной картины. Его опыт подсказывает, что такое естественно для преломления лучей в стеклянной прозрачной призме.

Перестановке частей с поворотом - когда меняется ориентиры верха и низа и изображение в перевернутой части оказывается резко контрастным с исходным фоном - дает другой эффект - зеркала. Это опять-таки связано нашим зрительным опытом. Мы воспринимаем зеркало, как зеркало, не изолированно, само по себе, а потому что оно всегда дает контрастный по отношении к фону тип изображения.

Оказалось, что каждое изображение таит в себе свои возможности вмешательства и создания объектов-фантомов. Не строил же Колейчук в действительности посреди горной долины гигантский стеклянный блок. Он специально использует изображения статичные, самые тривиальные, взятые из настенных календарей, чтобы показать радикальность происходящих с изображением превращений. А дальше - каждый фотограф может еще немного продлить удовольствие от работы над собственной фотографией.

Что в этой деятельности от искусства и правомерно ли вообще здесь говорить об искусстве? Что есть искусство: технология или образ? И что есть образ технологии?

У Колейчука было несколько излюбленных упражнений, которые он всегда давал студентам. Одно из них - нарезка фотоизображения на полосы, их нумерация, а затем перестановка или раздвижка. В одном случае получаются симметричные картинки, в другом - два клона одного и того же изображения с пробелами. Если нарезать на полосы два изображения - одно по горизонтали, а второе - по вертикали и затем сплести из них что-то вроде коврика - получится интересный эффект перетекания одной картинки в другую. В этом простейшем опыте, основанном на композициях Колейчука, проявляется сразу несколько закономерностей. Во-первых, возникает повторяющийся или меняющийся ритм структуры ткани. Во-вторых, кодировка полос, участвующих в плетении такого «коврика», программирует итоговый результат - восстановление разрезанного на полосы изображения. В-третьих, за счет взаимного переплетения двух изображений (одни полосы вертикальные, другие - горизонтальные) - воз- никает новое визуальное поле, отличное от двух исходных изображений.

Другой, также несложный опыт - это уже упоминавшийся «самоколлаж» - разрезка фотоизображений таким образом, чтобы перестановкой частей получить новые формы и объекты. Упражнения просты, быстро выполняются, результат получается мгновенно. Сама постановка задания, его материал уравнивают как людей получивших специальное художественное образование, так и новичков, что бывает важно для достаточно пестрого состава студентов в современных вузах.

Благодаря этим упражнениям остается память об изобретательстве, комбинаторике. Сохраняется на уровне «мышечной» памяти, технологической памяти об операциях. Для художника же этот вид деятельностной, операциональной памяти - самый главный.

Относительно же технологии Колейчук отвечал в 2017 году на мой вопрос:

"Всякое средство в искусстве имеет только ему присущие визуальные свойства. Конечно, возможны имитации (вспомним направление фотореализма, но это - крайний случай). Образы и виды трансформации бумаги разнообразны, но ограничены правилами и свойствами собственно бумаги. Вернее говорить о трансформации плоскости или плоского материала».

Пожалуй, только у Колейчука есть пример движущегося фотомонтажа или самоколлажа. Из цветной репродукции с картины Айвазовского «Лунная ночь у взморья» 1817 года он вырезал круг в том месте, где художник нарисовал Луну. Круг этот медленно поворачивается мотором, и Луна оказывается то Луной, то бликом на оранжево-коричневом шаре, который неведомым образом вдруг выпучивается из плоской картины. Все дело в появлении контрастов на границах вращающегося круга и в ориентации светлого пятна, которое в какой-то момент удивительно удачно имитирует блик. Так поочередно фантомный объект то появлялся, то исчезал в поле изображения.

Колейчук написал фактически первую книгу о кинетизме на русском языке. Он всегда работал одновременно и как художник, проектировщик и конструктор, исследователь и экспериментатор, ученый и теоретик в лаборатории архитектурной бионики у Сергея Лебедева, в Институте Теории и истории архитектуры (ЦНИИИТИА) у Хан-Магомедова или позднее во ВНИИТЭ. До 
сих пор книжкой Колейчука «Кинетизм» - у нас нет другого аналогичного издания с подобной исторической и творческой панорамой работ пользуются как исследователи, так и студенты.

Считал ли он свои композиции частью общемирового движения в искусстве 1960-х годов?

«В 60-е годы в Москве работала группа «Движение», которая занималась кинетическим искусством, модным в мире направлением. Мне это было интересно, и я плотно контактировал с ней и ее лидером - Л. Нусбергом».

«1964-1965 годы - это начало сотрудничества с группой "Движение», первые попытки создания которой были предприняты еще в 1962 году учащимися Московской средней художественной школы при Суриковском институте и лидером группы Львом Нусбергом.

Это был период бури и натиска, на общество обрушилась лавина новой или ранее недоступной информации из различных областей культуры: философии, литературы, кино, театра, живописи, дизайна, архитектуры, были реабилитированы челье научные направления - кибернетика, генетика, психология. Активизация интеллектуальной деятельности, поиск новых ориентиров, импульсов художественного творчества с неотвратимостью привели к «междисциплинарному» обмену информацией, к размыванию границ узаконенных видов искусства. Физики и лирики, кибернетика и искусство, НТР и художественное творчество, техническая эстетика, города будущего сам воздух был наполнен этими проблемами» ${ }^{9}$.

На этом фоне «оттепели» выразительные средства одних видов искусства интегрировались в другие. Научное, техническое и художественное творчество, исполнительские и изобразительные виды искусства легко ассимилировались друг другом. Проект «Тотального театра» Колейчука также относится к этому времени. Формальнокомпозиционной основой, прототипами многих композиций членов группы «Движение» стали пространственные композиции Наума Габо - как строго геометрические, так и свободные контуры, обтянутые нитями. Как группа она заявила о себе на выставке кинетического искусства в Доме архитектора в Ленинграде в 1965 году. За ней последовала выставка кинетического искусства в Клубе института атомной энергии в Москве в 1966 году. Скорее всего, с этого момента

9. Колейчук В.Ф. Кинетизм. - Москва: Галарт, 1994, с. 48 все, что производил, изобретал, строил Колейчук, можно было отнести к кинетическому искусству. Включая и проекты мобильной трансформирующейся архитектуры. В этих моделях, составленных из плоских конструктивных деталей, за счет натяжки специально трассированного троса, происходит «самовозведение» (еще один авторский термин) будущего здания за считанные секунды.

Есть ли у современных композиторов музыкальные аналогии тем конструкциям, на которых Колейчук играл как на музыкальных инструментах?

«Аналоги моим музыкальным инструментам можно найти и в фольклоре (вспомним игру на пиле), и в профессиональных оркестрах (итальянские трубчатые колокола). Самонапряженные колокола - это одно, а овалоид - другое.

Овалоид - два дюралюминиевых диска овальной формы, стоящие на деке. Возможны три типа звукоизвлечения: смычком, ударными и различными терками из кожи, стекла и дерева. Инструмент имеет богатую тембровую окраску и широкий звуковой диапазон по высоте и силе звука, поэтому я называю его звуковым металлосинтезатором».

В конструкциях Колейчука, казалось, сами элементы предназначены для извлечения звука: трубки разной длины, свободно подвешенные в воздухе, при ударе издают долго тянущиеся звуки разной высоты. Проволочные растяжки - это струны. Трубки в этом случае могут играть роль резонаторов.

Искусство Колейчука - это всегда визуальный сплав проектности, интуиции и лабораторного поиска. И еще - собственных исследований истории. Он объяснил современникам, в чем был смысл состоявшейся 100 лет назад в Москве первой в мире и единственной в своем роде выставки пространственных конструкций, известной в истории искусства под названием «Вторая весенняя выставка ОБМОХУ», (сокращенно Общества молодых художников). К выпускникам ВХУТЕМАСа - Владимиру и Георгию Стенбергам и Константину Медунецкому присоединились Александр Родченко и Карл Иогансон. C 2006 года эта выставка в виде полной реконструкции в зале ГТГ стала доступной для зрителей.

Когда Колейчук занимался реконструкцией выставки ОБМОХУ - постоянно подвергал сомнению всю доступную информацию. Оказалось, что на выставке ОБМОХУ в 1921 году стояли одни работы братьев Стенбергов, а в 1970-е несмотря на внешнюю похожесть, были созданы совершенно другие авторские реконструкции. Обычно 
считалось, что на выставке было одно количество произведений, но на фотографии обнаружил Колейчук еще один ранее неизвестный объект. В архиве ГТГ нашелся огромный, по нынешним временам, стеклянный негатив - $18 \times 24$, снятый неведомым фотографом мастерской репродукций Отдела Изо Наркомпроса весной 1921 года. С этого негатива, наверное, впервые после 1920-х годов были сделаны отпечатки. Колейчук не просто нашел тот настоящий зал в доме на Дмитровке, бывший салон Михайловой, где размещалась выставка, но и отыскал в архиве планы здания и успел зайти в это помещение в краткий миг смены хозяев и начинавшегося ремонта.

Реконструкция этой выставки была сделана с полным чувством художественной ответственности перед своими предшественниками. В этом проекте активно участвовали сын Колейчука Дмитрий и его дочь Анна. Важно, что они оба сохраняют секреты и знания моделирования подобных типов структур, самонапряженных конструкций, которые испытывал на стабильность Карл Иогансон, а Вячеслав Колейчук превратил в огромное семейство композиций различных масштабов, назначений и очертаний.

Он своем пристрастии к авангарду и конструктивистам Колейчук написал так:

«Омущаю духовное родство с А. Родченко, с его временем. Хорошее было время - конструктивное. Люди изобретательные, романтические. Такие как Родченко "разрешили» своим творчеством и нам поизобретать, поэкспериментировать, поиграть воображением» ${ }^{10}$.

Вячеслав Фомич Колейчук скончался в первый день Пасхальной недели, утром 9 апреля 2018.

Внешние знаки признания и авторитета - Лауреат Государственной премии 1994 года, профессор МАРХИ, академик, член Национальной академии дизайна, член творческих союзов архитекторов, художников и дизайнеров - давали площадку и возможность делиться своими

10. В. Колейчук. Запись в книге отзывов. 3 февраля 1993 г. Архив А. Родченко и В. Степановой находками и экспериментами как художникаизобретателя.

Он один из родоначальников кинетизма в СССР, человек, который мог превратить в объект искусства научное открытие, геометрический чертеж или банальный факт обыденной жизни, сломать устойчивый стереотип восприятия (вроде «невозможности» построения «невозможных» фигур), открывая нам бесконечность вариантов структур окружающего нас мира.

Он оставил после себя удивительные вещи: ажурные легкие конструкции из металла, стоящие в Олимпийской деревне Москве, объекты для саммита в Санкт-Петербурге, самонапряженные колокола и другие конструкции в Коломне, стоящие где-то в Германии парковые скульптуры, он воссоздал в ГТГ целый зал предшественников искусства высоких технологий, выставку ОБМОХУ 1921 года, отдав дань изобретательству Родченко, братьев Стенбергов, Иогансона и Медунецкого.

Он оставил после себя книги и статьи, проекты и схемы выкроек, модели и объекты, фотографии и фильмы, телепередачи.

Он оставил идеи, технологии, представления о мире. Показывая какой-либо найденный им принцип, он радовался возможности поделиться этим как новой творческой головоломкой. Он радовался от того, что ему удалось понять и объяснить закон получения объемных структур из плоскости, соединение нитей и стержней в пространстве или механизм появления оптических иллюзий. Как актер или фокусник он показывал все эти принципы в действии, вдохновляя молодых художников постоянно задавать себе «детские» вопросы: почему мы видим мир так, а не иначе, что такое оптическое движение и откуда возникает «муаровый эффект», почему в нашем окружении преобладают прямоугольные системы проектирования и отображения пространства, как и во что трансформируется плоскость, сколько вантовых связей в самонапряженной конструкции можно оставить, чтобы система сохраняла стабильность. Он оставил нам это свое неуемное любопытство.. 


\section{БИБЛИОГРАФИЯ}

1. В.Ф. Колейчук. Моя азбука.- Москва: МГХПА им. С.Г. Строганова, 2012

2. Колейчук В.Ф. Кинетизм. М.: Галарт, 1994

3. Лаборатория будущего. Кинетическое искусство в России. - Санкт-Петербур: АНО "СХ", Центральный выставочный зал "Манеж", 2020. 592 с., ил.

4. Gluibizzi, A. 2021. Art and Design in 1960s New York. London, UK; New York, NY, USA: Anthem Press. DOI:10.2307/j.ctv1gbrrk9

5. Topper, D., \& Holloway, J. 1980. Interrelationships between the Visual Arts, Science and Technology: A Bibliography. Leonardo, 13(1), 29-33. DOI:10.2307/1577916
6. Applin, J., Spencer, C., \& Tobin, A. (Eds.). 2018. London Art Worlds: Mobile, Contingent, and Ephemeral Networks, 1960-1980. University Park, Pennsylvania: Penn State University Press. DOI:10.5325/j.ctv14gp4cg

7. Zinman, G. 2020. Making Images Move: Handmade Cinema and the Other Arts. Oakland, California: University of California Press. DOI:10.2307/j.ctvqr1bkx

8. George F. Flaherty. 2014. Responsive Eyes: Urban Logistics and Kinetic Environments for the 1968 Mexico City Olympics. Journal of the Society of Architectural Historians, 73(3), 372-397. DOI:10.1525/ jsah.2014.73.3.372

9. Galeyev, B. 1991. Musical-Kinetic Art in the USSR. Leonardo, 24(1), 41-47. DOI:10.2307/1575467 